\title{
Sunflower Stalk Diseases Initiated Through Leaf Infections
}

\begin{abstract}
Robert Harveson, ${ }^{\dagger}$ Panhandle Research and Extension Center, University of Nebraska, Scottsbluff, 69361; Febina Mathew, Department of Agronomy, Horticulture and Plant Science, South Dakota State University, Brookings, 57007; Thomas Gulya, United States Department of Agriculture-Agricultural Research Service, Northern Crop Science Laboratory, Fargo, ND 58108 (Retired); Samuel Markell, Department of Plant Pathology, North Dakota State University, Fargo, 58102; Charles Block, Seed Science Center, lowa State University, Ames, 50011; and Susan Thompson, University of Southern Queensland, Toowoomba, Australia (Retired)
\end{abstract}

Accepted for publication 13 February 2018.

Stalk diseases in sunflower (Helianthus annuus L.) can be broadly categorized into two major groups: those that are initiated through leaf infections that progress to the petiole attachment on plant stems, and those diseases caused by soilborne pathogens infecting plants through the roots. This article will concentrate on comparing and contrasting three stalk diseases on sunflower that originate via leaf infections: Phoma black stem, Phomopsis stem canker, and bacterial stalk rot.

\section{Host: Sunflower (H. annuus L.)}

Disease: Phoma black stem.

Pathogen: Phoma macdonaldii (syn. Leptosphaeria lindquistii Frezzi) (Frezzi 1968). Originally classified as Phoma oleracea var. helianthi-tuberosi Sacc. (MacDonald 1964), which is a synonym of the saprophyte Phoma herbarum Westend. P. macdonaldii is tentatively being reclassified as Plenodomus lindquistii (Frezzi) Gruyter, Aveskamp \& Verkley (Aveskamp et al. 2008). Other species of Phoma, all saprophytes or opportunistic pathogens, have been isolated from various Helianthus species on live or overwintered tissue, including Phoma nebulosa (Fr.) Mont., P. septicidalis Boerema (Coniothryium telephii [Allescher] Verkley \& Gruyte), P. acutata Fuckel (Leptosphaeria doliolum [Fries] Cesati \& de Notaris), and P. sanguinaolenta Grove (L. purpurea Rehm) (Boerema et al. 2004).

Taxonomy: Kingdom Fungi; phylum Ascomycota; subdivision Pleosporomycetidae; class Dothideomycetes; order Pleosporales; family Leptosphariaceae; genus Leptospharia; and species $L$. lindquistii.

\section{Symptoms and Signs}

Stem lesions most frequently result from leaf infections that progress down the petiole to the stem (MacDonald 1964; Maric and Schneider 1979) (Fig. 1). Airborne ascospores of L. lindquistii germinate in guttation drops at leaf margins and colonize major leaf veins, turning them necrotic, with little or no chlorosis, and thus the foliar disease phase is often overlooked. Once the pathogen reaches

\section{Corresponding author: Robert Harveson; E-mail: rharveson2@unl.edu}

Funding: This work was funded by USDA NIFA - Crop Protection and Pest Management Program through the North Central IPM Center (grant no. 2014-7000622486).

(C) 2018 The American Phytopathological Society the petiole, it becomes noticeably black, and the entire leaf blade wilts as the water supply is curtained. The initial infections usually occur on lower leaves of the canopy, thus further escaping notice. As the pathogen reaches the base of the petiole, a black circular to elliptical lesion will form that can eventually encircle the stem (Fig. 2 ). The margin is often distinctly delimited and seldom exceeds 5 to $6 \mathrm{~cm}$ in length. In contrast, a Phomopsis stem canker lesion is light to dark brown in color and can achieve 15 to $20 \mathrm{~cm}$ in length (Fig. 3). Phoma lesions are also usually superficial, and there is no pith degradation (Fig. 4), whereas a Phomopsis lesion will result in pith degradation to the point of producing a hollow stem and eventual lodging at that point (Fig. 5). Once mature, the small, black pycnidia, mostly buried in the epidermis, may be observed with a hand lens of 5 to $10 \times$. The fruiting structures of the sexual stage (L. lindquistii), properly termed pseudothecia, will form after the stems have overwintered (Donald et al. 1986; Frezzi 1968).

Basal stem lesions (Fig. 6), occurring at the soil line, can occur with Phoma-contaminated seeds, or owing to early seedling infection via roots (Al Fadil et al. 2009; Donald et al. 1987; Masirevic et al. 2014). Basal stem lesions are similar in appearance to those occurring at leaf axils. When stem-feeding insects such as Apion and Cylindrocopturus stem weevils oviposit in leaf axils, a stem lesion will form without leaf infection. When the eggs hatch, the Phoma-contaminated larvae will burrow upward into the pith, carrying Phoma, and cause extensive pith degradation, premature maturity, and death of the plant (Donald and Venette 1983; Gaudet and Schulz 1984; Gulya and Charlet 1984).

\section{Host Range}

The primary host of $P$. macdonaldii is cultivated sunflower (H. annuus L.). The pathogen has also been isolated from lesions on annual and perennial wild Helianthus species, all native to North America. It does not infect other Asteraceae genera, but there are many other Phoma species reported on other Asteraceae (Boerema et al. 2004).

\section{Geographic Distribution}

P. macdonaldii, originally identified in North America (MacDonald 1964), has been recorded from many countries in North and South America (Bruni 1965; Gulya and MacArthur 1984; Kandel and Gulya 2016), Europe (Maric and Schneider 1979; Penaud and Peres 1994), Asia, Africa, and Australia (Miric et al. 1999; Wu et al. 2012). In contrast to its impact on the U.S. crop (Carson 1991), unless vectored by stem-boring insects, $P$. macdonaldii is felt to be a significant pathogen on sunflower in Europe, where significant yield losses have been reported from France (Penaud and Peres 1994). 


\section{Pathogen Isolation}

Isolation from diseased plants, whether the lesion be on stems, petioles, or leaves, is best done with a semiselective medium because $P$. macdonaldii can be overgrown with saprophytic Alternaria,

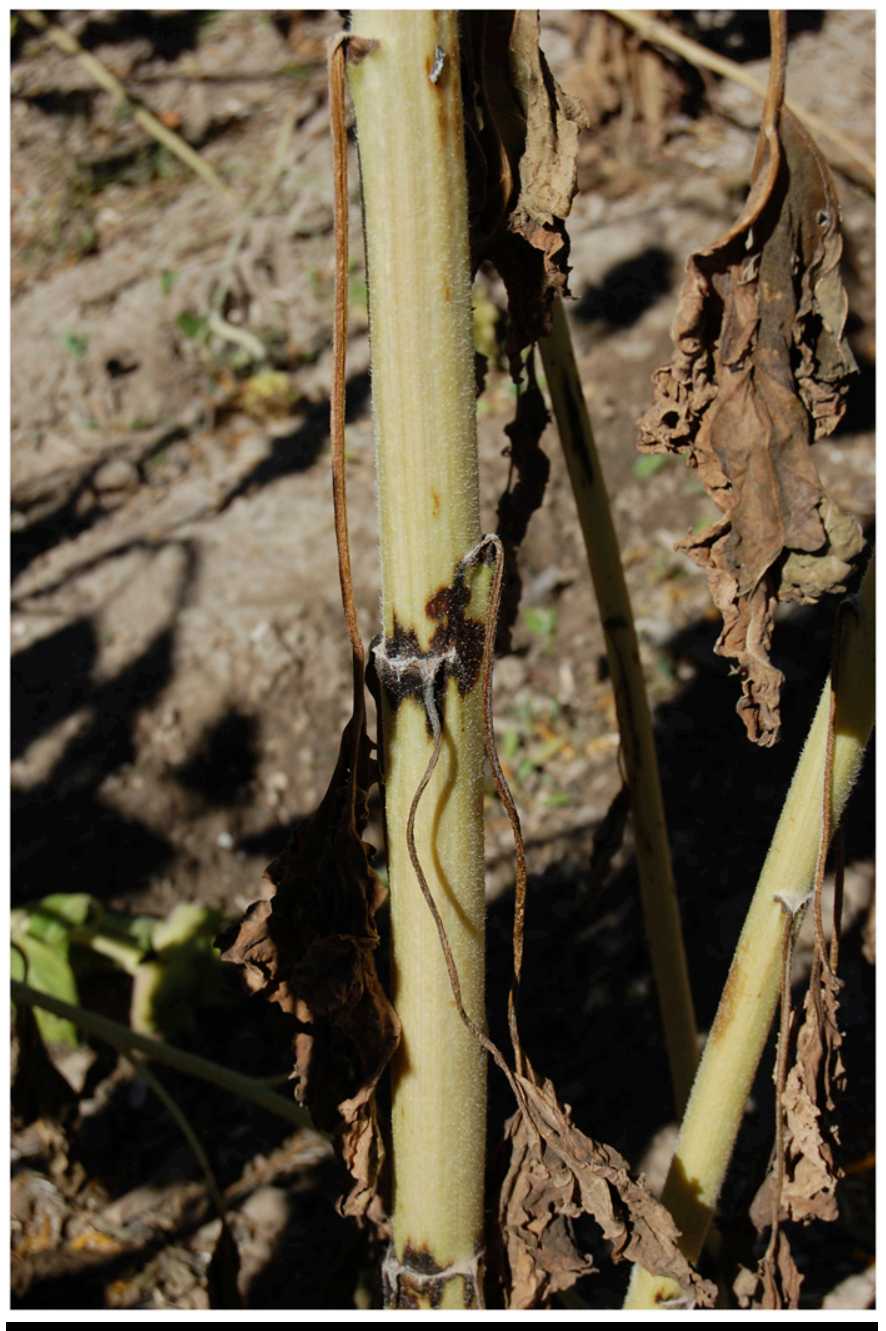

FIGURE 1

Early stem lesions forming at petiole attachments.

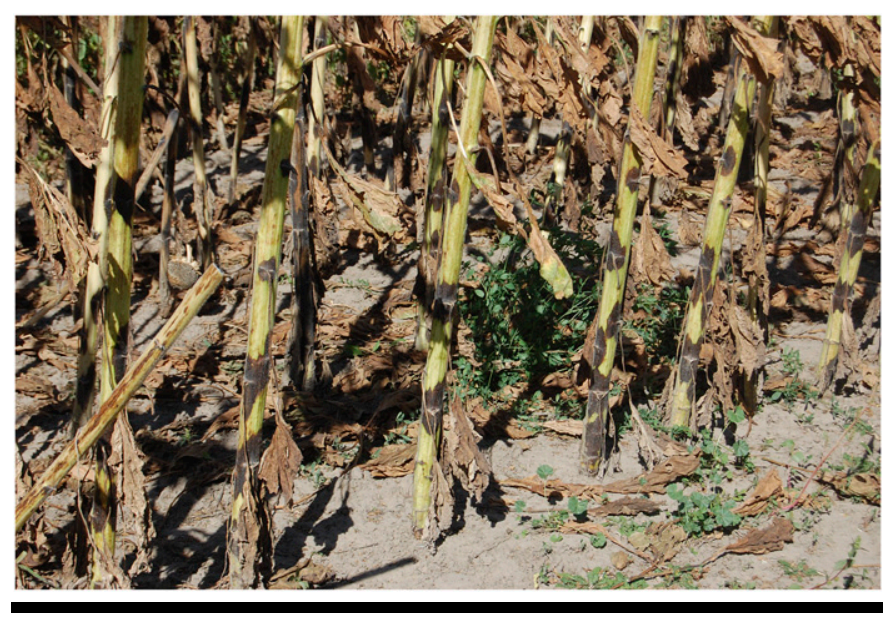

FIGURE 2

Multiple lesions on sunflower stems due to Phoma black stem. Note some have completely encircled stems.
Rhizopus, and other genera. One semiselective medium (Donald and Venette 1983), specifically tested with $P$. macdonaldii, utilizes several fungicides, whereas another generic Phoma-selective medium relies on manganese chloride to exclude other fungi (Sørensen et al.

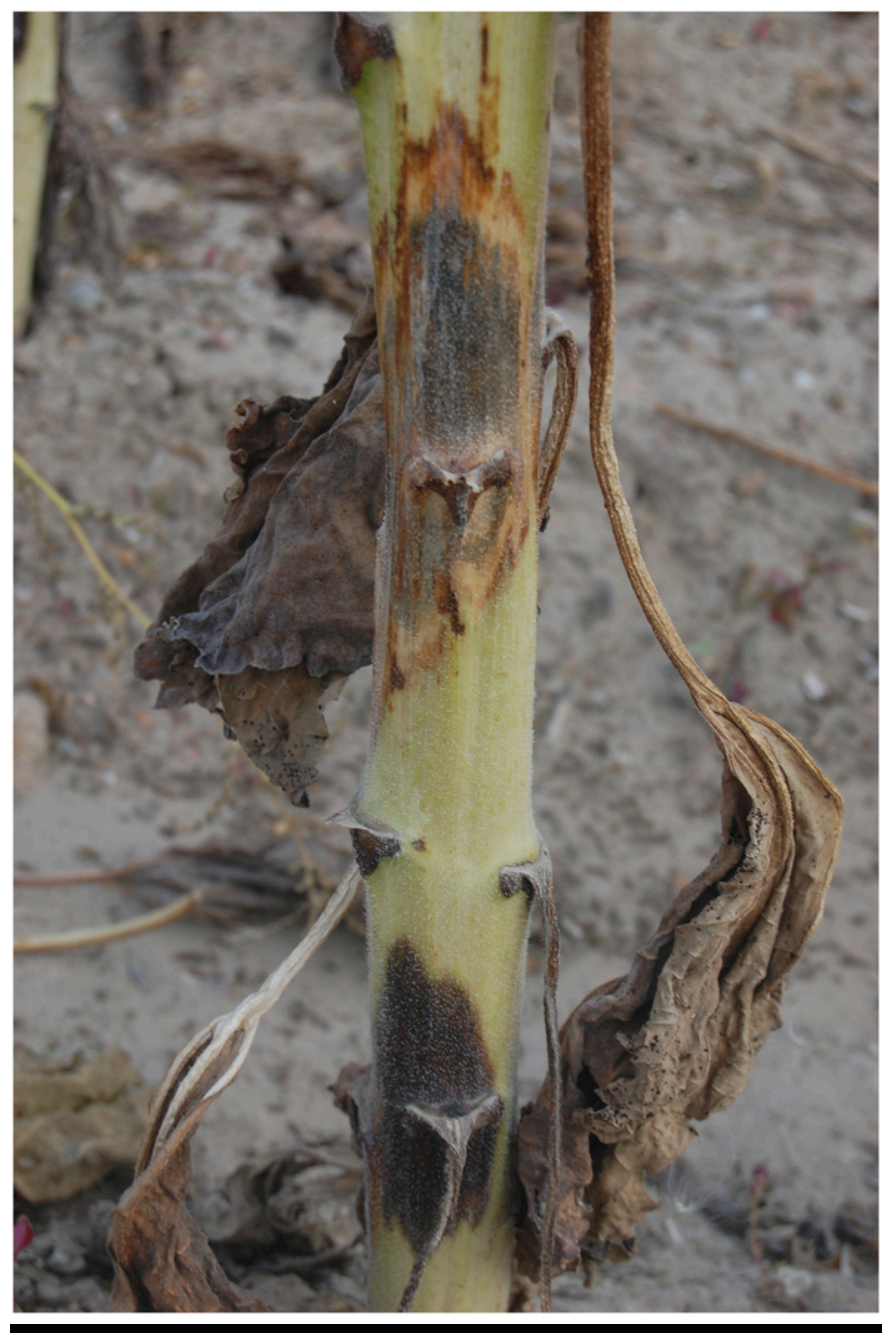

FIGURE 3

Infected sunflower stem exhibiting lesions caused by both Phomopsis stem canker (top) and Phoma black stem (bottom).

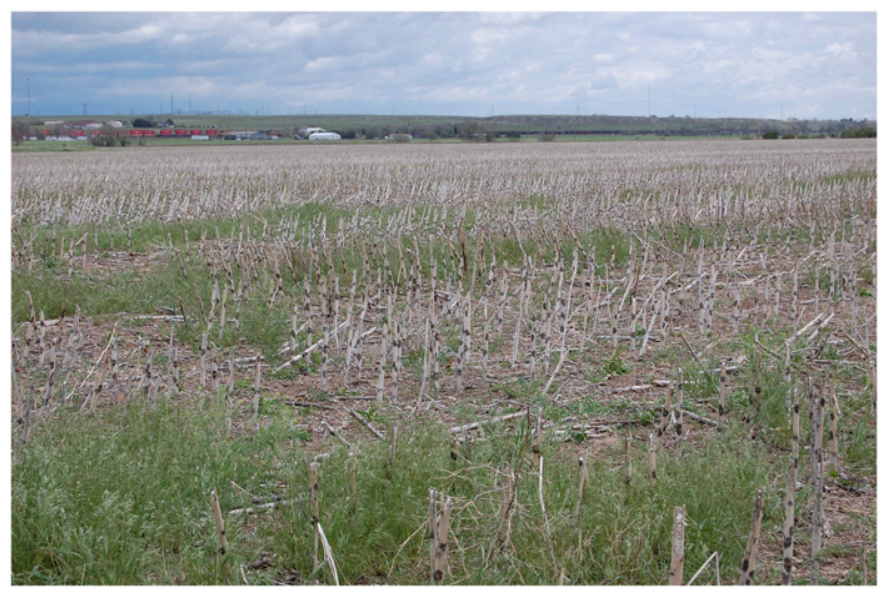

FIGURE 4

Sunflower field after harvest showing degree of infection by Phoma black stem. Note lack of stalk lodging. 
2009). Fungal growth of pure cultures can be done on conventional mycological media, including acidified potato dextrose agar (APDA, $\mathrm{pH}$ is adjusted to 4.5 to 5.0 using lactic acid), potato dextrose agar (PDA), potato carrot agar, oatmeal agar (OA), and malt agar (MA) (Boerema et al. 1994; Larfeil et al. 2002; Maric and Schneider 1979).

\section{Pathogen Identification}

$P$. macdonaldii belongs to the section Plenodomus, as currently categorized by Boerema et al. (1994) and other Phoma taxonomists. The 26 species of Phoma in this section are characterized by thickwalled pycnidia, with a resultant small lumen bearing the pycniospores. The standard media for Phoma identification are APDA and OA, optimal for pycnidia production, and MA, optimal for crystal production (Noordeloos et al. 1993). On APDA, ivory-white colored colonies that have a fluffy appearance are produced in

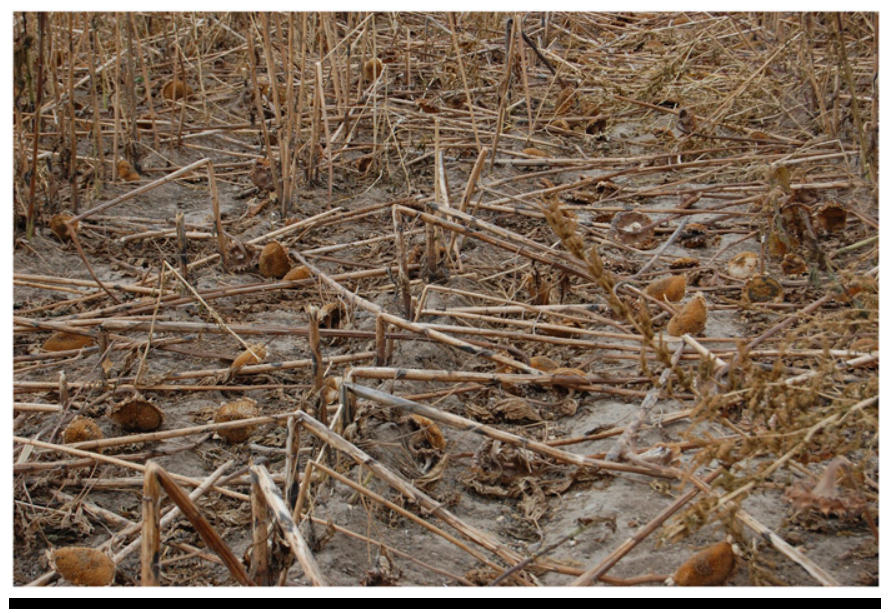

FIGURE 5

Sunflower field at harvest badly affected by Phomopsis stem canker. Note the numerous lodged plants.

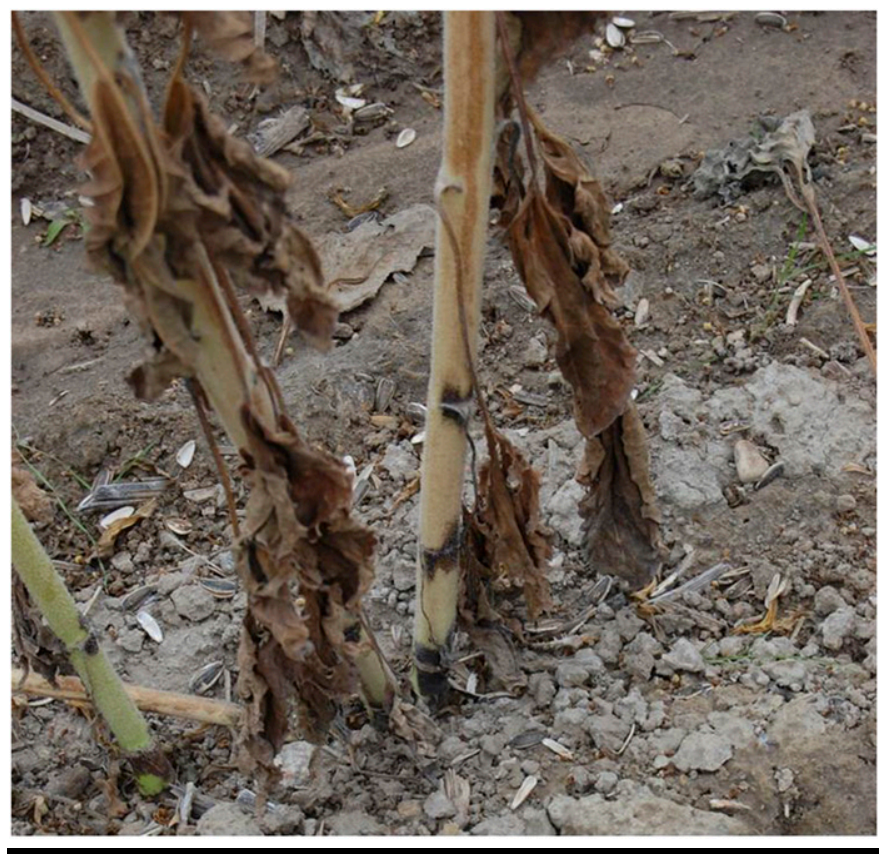

FIGURE 6

Phoma black stem lesions girdling stems at the soil surface.
3 days after incubation. A large number of brown-colored pycnidia will be formed on APDA, either separately or in clusters; from the ostiole of the pycnidia, a pale pink gelatin-like substance (pycnidiospores) may be exuded (Fig. 7). On OA, P. macdonaldii generally displays a 7-day growth rate of 25 to $45 \mathrm{~mm}$ and has whitish, cottony aerial mycelium. There is a great deal of variability in $P$. macdonaldii colony morphology, however, and colony color may vary from white to gray to olive green (Fig. 8). The colony reverse is generally citrine to olive green, often with white (occasionally apricot) granular crystals. Old cultures may display a pink or red color (Fig. 9), which characteristically turns blue or purple with a drop of $1 \mathrm{~N} \mathrm{NaOH}$. Pycnidia production varies considerably between isolates, ranging from 15 to $50 / \mathrm{mm}^{2}$ (Roustaee et al. 2000). Pycnidia in culture are subglobose, spherical, or oblate with very short or no necks, and they range in size from 70 to $10 \mu \mathrm{m}$, while on dead stems they may reach $300 \mu \mathrm{m}$ in diameter. Conidia (pycniospores) are highly variable in size, generally in 5 to $9 \times 1.5$ to $3 \mu \mathrm{m}$ range, single-celled, ovalshaped, and are eguttulate (lacking oil droplets, which are characteristic of other Phoma species).

\section{Pathogen Storage}

For a thorough discussion of various long-term storage methods, consult Dhingra and Sinclair (1995). Agar slants, covered with sterile mineral oil and held at $4^{\circ} \mathrm{C}$, will preserve viability of $P$. macdonaldii for up to a year. Another method, tested with P. macdonaldii, involves growing the fungus on sterilized sunflower stem pieces until pycnidia form and then storing the colonized tissue under calcium chloride granules at $6^{\circ} \mathrm{C}$ (Larfeil et al. 2002). Longer term viability is best accomplished with storage at $-80^{\circ} \mathrm{C}$ or in liquid nitrogen.

\section{Pathogenicity Tests}

Although root immersion with a mycelial suspension can successfully initiate Phoma premature ripening (Donald et al. 1987), it is time consuming, and all current inoculation methods use conidia ( $10^{6}$ conidia/ml; Larfeil et al. 2002 ; Seassau et al. 2010) or mycelial plugs on stems, with or without wounding (Dedić 2012; Larfeil et al. 2002; Roustaee et al. 2000; Seassau et al. 2010). Greenhouse inoculations of 12-day-old plants may be evaluated within 1 to 2 weeks postinoculation, and the results agree with field observations of mature plants. Lesion length, rated on a 1 to 9 scale (Seassau et al.

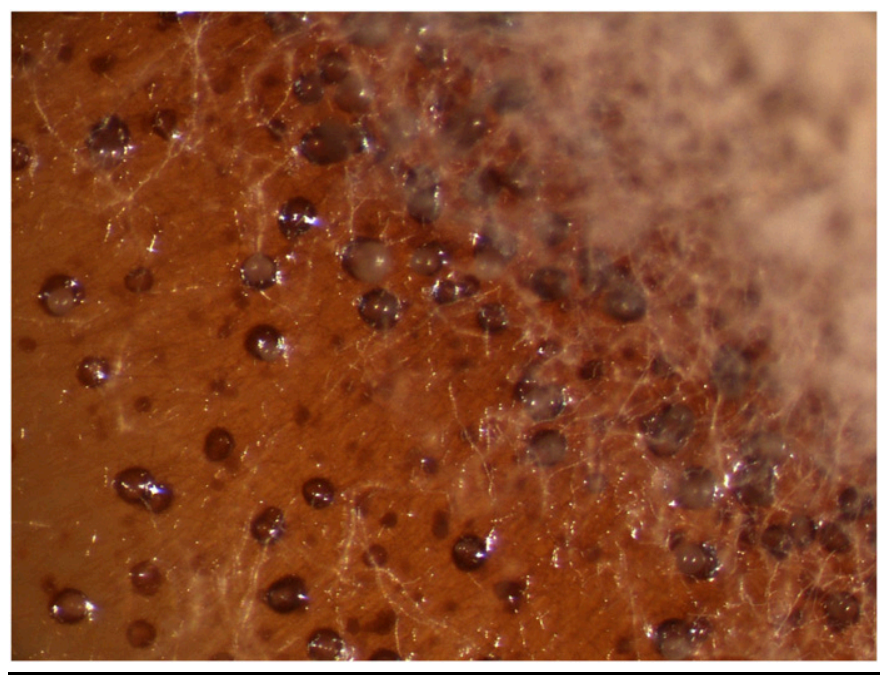

FIGURE 7

Mature pycnidia characteristic of Phoma with conidia oozing out. 
2010), rather than the rate of lesion expansion, is the best indicator of plant resistance (Schwanck et al. 2016), but the authors also noted that leaf number and plant height were highly correlated with Phoma resistance, and thus morphological characters are predictive of resistance as well. Owing to its low economic impact on U.S. sunflower, there is scant information on the performance of public germplasm. In contrast, the bulk of research on resistance evaluation is being done in France and other EU countries.

\section{Host: Sunflower (H. annuus L.)}

Disease: Phomopsis stem canker.

Pathogens: Diaporthe helianthi Muntañola-Cvetkovic, Mihaljcevic and Petrov (syn. Phomopsis helianthi Muntañola-Cvetkovic, Mihaljcevic and Petrov) (Hajdu et al. 1984; Herr et al. 1983; Mathew et al. 2015a; Meyer et al. 2009; Yang et al. 1984), Diaporthe gulyae Shivas, Thompson and Young (Mathew et al. 2015a; Thompson et al. 2011), Diaporthe stewartii Harrison (Olson et al. 2017), Diaporthe kongii Shivas, Thompson and Young (Thompson et al. 2011), Diaporthe

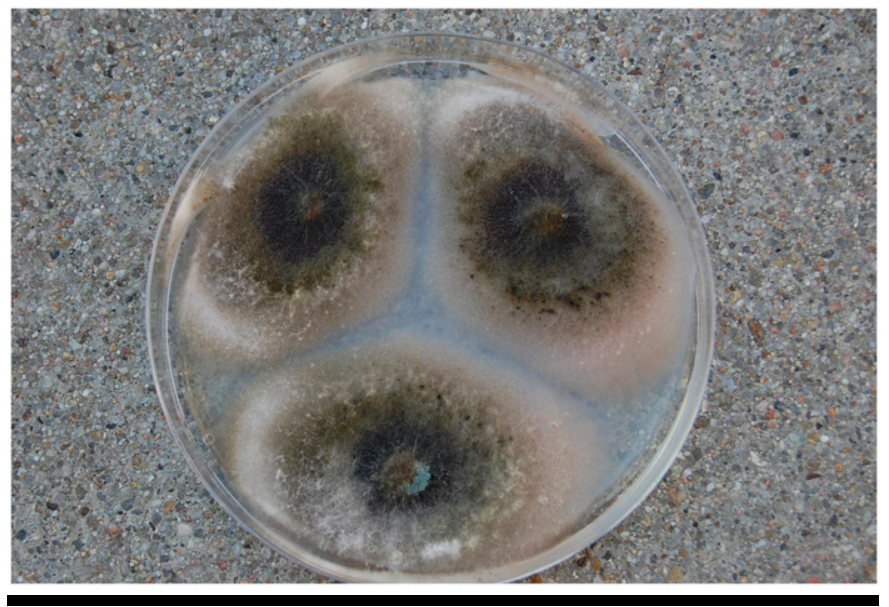

FIGURE 8

Culture of Phoma macdonaldii.

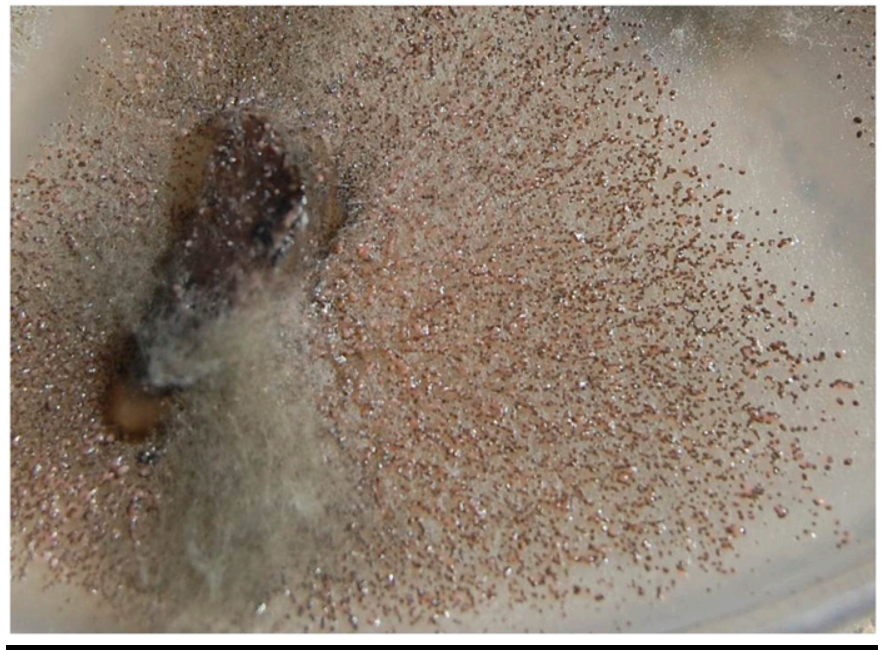

FIGURE 9

Close-up image of older culture of Phoma. kochmanii Shivas, Thompson and Young (syn. Diaporthe sojae Lehman; Thompson et al. 2011), and Diaporthe novem Santos, Vrandečić and Phillips. Four other species of Diaporthe have been isolated either from seeds, stems, roots or residue of sunflower in the United States or Australia (Diaporthe longicolla (Hobbs) Santos, Vrandecic and Phillips, Diaporthe masirevicii Shivas, Morin, Thompson and Tan; Diaporthe miriciae Shivas, Thompson and Tan [syn. Diaporthe sojae Lehman], Diaporthe sackstonii Shivas, Thompson and Tan [F. Mathew and T. Olson, unpublished; Thompson et al. 2015]). Diaporthe serafiniae Shivas, Thompson and Tan was isolated from the seed of ornamental sunflower, H. annuus (Thompson et al. 2015).

Taxonomy: Kingdom Fungi; division Ascomycota; subdivision Pezizomycotina; class Sordariomycetes; order Diaporthales; family Diaporthaceae; genus Diaporthe; and species D. helianthi, D. gulyae, and other species of Diaporthe.

\section{Symptoms and Signs}

Lesions initially appear as brown spots with a yellow chlorotic margin at the edge of older leaves of the sunflower plants (Fig. 10). As the disease spreads through the leaf veins and petioles, they become necrotic and cause death of the entire leaf. The infection spreads through the petioles, where moisture accumulates, eventually reaching the main stalk of the sunflower plant. Lesions on the stem develop a wet appearance, appear tan to brown in color (Fig. 11 ), have a sunken border, increase in length (often reaching 15 to $20 \mathrm{~cm}$ ), and eventually girdle the stalk, whereupon plants wilt and lodge (Fig. 12). Phomopsis stem canker causes the pith to degrade to the point that the stalk is easily crushed under moderate thumb pressure. These symptoms appear between bud initiation and flowering growth stages of the sunflower field (Herr et al. 1983; Masirevic and Gulya 1992).

Symptoms of Phomopsis stem canker can be easily confused with those produced by other pathogens. For example, lesions produced by $P$. macdonaldii on sunflower are usually smaller, black colored, entered around the nodes of the plant (Figs. 3 and 4), and do not cause pith degradation or lodging. Lesions produced by Sclerotinia sclerotiorum (Lib.) de Bary, the causal pathogen of Sclerotinia midstem rot, resemble those produced by species of Diaporthe; however, the sunflower plant has black sclerotia forming in the stem (Gulya at al. 1997).

\section{Host Range}

Between the two predominant pathogens (D. helianthi and D. gulyae) causing Phomopsis stem canker of sunflower in the world, D. helianthi infects sunflower (Herr et al. 1983; Mathew et al. 2015a), wild sunflower (Mihaljčević et al. 1985), Xanthium italicum (Vrandecic et al. 2010), Xanthium strumarium (Vrandecic et al. 2010), Arctium lappa (Vrandecic et al. 2010), and grapevine (Vitis vinifera) (van Niekerk et al. 2005). D. gulyae infects sunflower (Mathew et al. 2015a, b; Thompson et al. 2011), soybean (Glycine $\max$ L.) (Mathew et al. 2018; Thompson et al. 2015), and saffron thistle (Carthamus lanatus) (Ash et al. 2010).

\section{Geographic Distribution}

D. helianthi has been confirmed causing Phomopsis stem canker of sunflower in eastern Croatia, France, South Africa, and the United States based on culture characteristics and DNA sequence analyses (Mathew et al. 2015a; Says-Lesage et al. 2002; Udayanga et al. 2011). D. gulyae was confirmed causing Phomopsis stem canker of sunflower in the United States (Mathew et al. 2015a) and 
Canada (Mathew et al. 2015b). In Australia, among the several species of Diaporthe reported on sunflower, D. gulyae, D. kochmanii (syn. D. sojae), and D. kongii cause Phomopsis stem canker (Thompson et al. 2011).

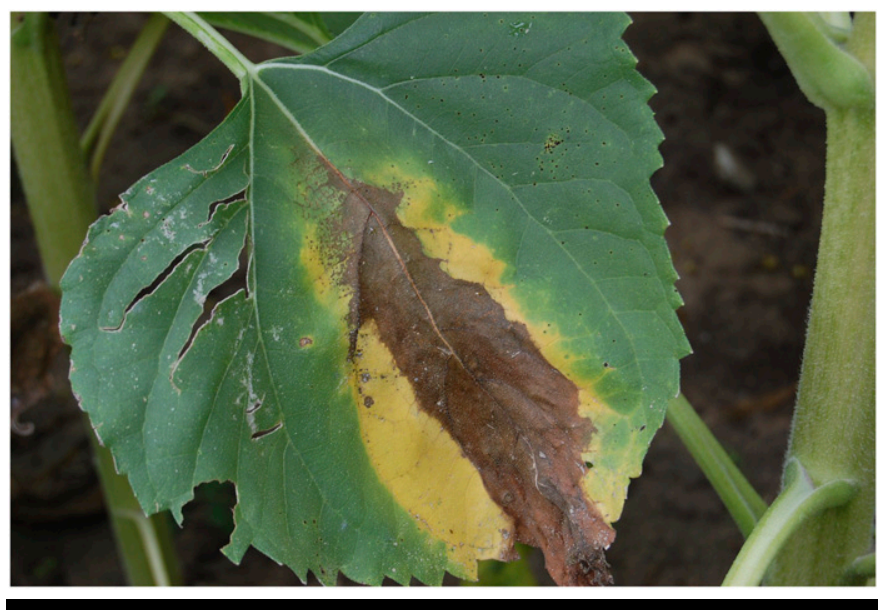

FIGURE 10

Leaf lesion characteristic of infection by Phomopsis stem canker pathogens.

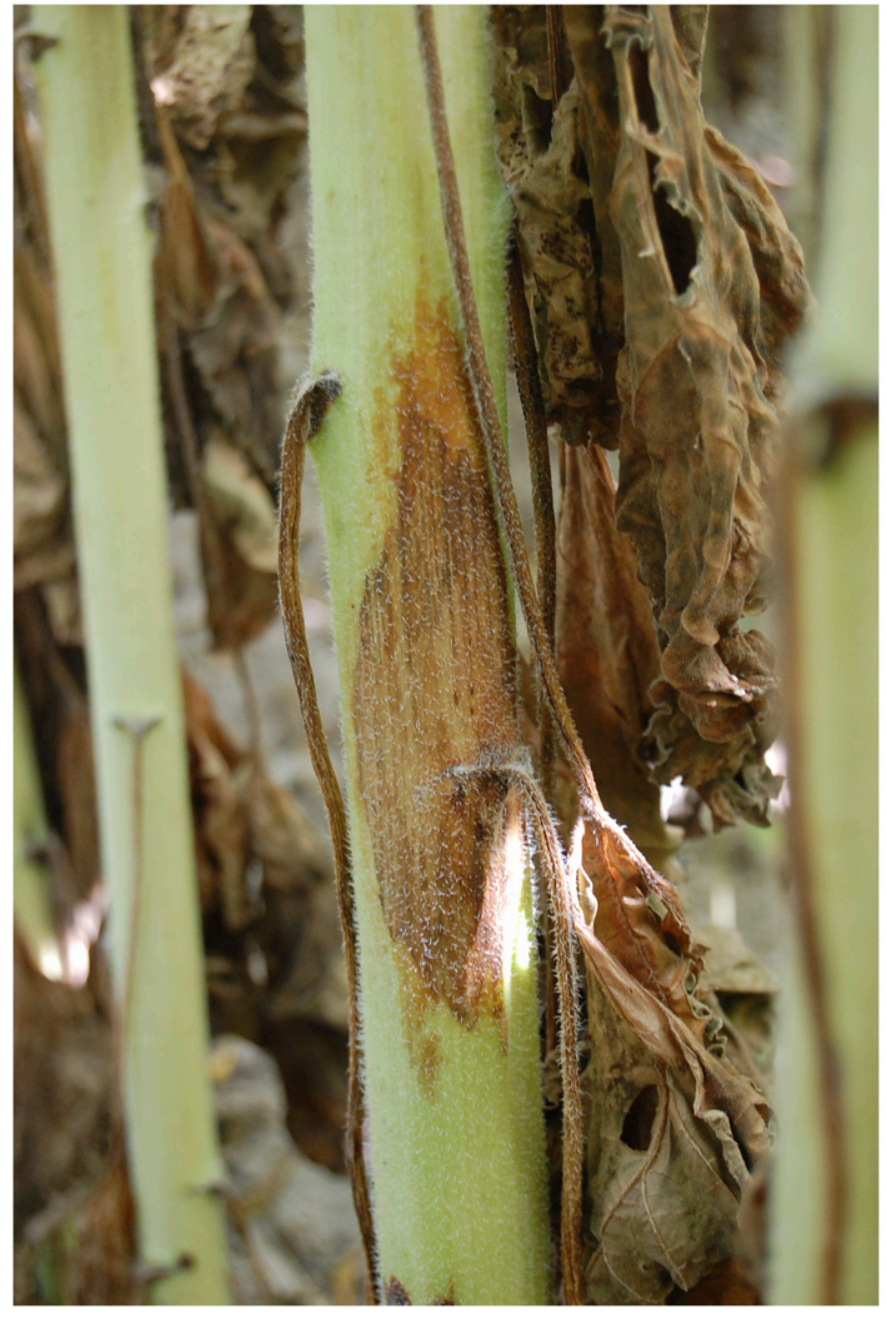

FIGURE 11

Light brown to tan lesion on stem of plant affected by Phomopsis stem canker.

\section{Pathogen Isolation}

Species of Diaporthe can be easily isolated from infected sunflower stalks on PDA (Becton, Dickinson and Company, Franklin Lakes, NJ, $39 \mathrm{~g} /$ liter, $200 \mathrm{mg}$ of streptomycin, pH 6 or following the protocol of Leslie and Summerell [2006]). Stem samples are washed in tap water for $2 \mathrm{~min}$ and cut into pieces (approximately $1 \mathrm{~cm} \mathrm{long}$ ). The pieces are surface sterilized in sodium hypochlorite $(0.05 \%)$ and ethanol $(70 \%)$ for $1 \mathrm{~min}$ each, rinsed in autoclaved distilled water, blotted between sterile filter papers, and placed on PDA. Plates are incubated at $25^{\circ} \mathrm{C}$ for 7 to 14 days under $12 \mathrm{~h}$ of alternating light and dark conditions. Cultures are scored for presence of Diaporthe based on morphological characteristics such as color and appearance of colony, arrangement and shape of pycnidia, and size of spores (Barnett and Hunter 1972; Mathew et al. 2015a; Thompson et al. 2015, 2011).

\section{Pathogen Identification}

For D. helianthi, colonies on PDA form less abundant white mycelium along with narrow greenish-yellow areas (Fig. 13, left). Reverse of culture on PDA appears white to tan color and has light brown scattered spots initially that later turn dark brown. The pycnidia formed are usually aggregate, rarely solitary, measuring 240 to $450 \times 230$ to $380 \mu \mathrm{m}$. They contain two types of conidia (Fig. 14): alpha-conidia, which are unicellular, colorless, elliptical, and 8 to $21 \times 1.7$ to $5.5 \mu \mathrm{m}$; and beta-conidia, which are unicellular, filiform, and 16 to $42 \times 0.5$ to $6.9 \mu \mathrm{m}$. The proportions of alpha- and betaconidia can vary between $D$. helianthi isolates and with production under natural conditions or in culture. For example, D. helianthi isolates from Minnesota, North Dakota, and South Dakota have only beta-conidia formed in culture, and they do not germinate (at least under laboratory conditions) (Mathew et al. 2015a). The ascoma (perithecia) of $D$. helianthi are 350 to $450 \mu \mathrm{m}$ in diameter with a prominent beak 350 to $600 \mu \mathrm{m}$ long on overwintered crop debris. Asci are colorless, 8 -spored, sac-like, and 44 to $67 \times 7.5$ to $12.5 \mu \mathrm{m}$. Ascospores are colorless, elliptical, uniseptate, and 9.2 to $19 \times 2.2$ to $7.5 \mu \mathrm{m}$.

For D. gulyae, colonies on PDA have scant aerial mycelium and slightly darker centers (Fig. 13, right). Pycnidia appear scattered on PDA (Fig. 15), subglobose, up to $3 \mathrm{~mm}$ diameter, and occasionally have ostiolate beaks up to $1 \mathrm{~mm}$ long. Alpha conidia are globose, subglobose, ellipsoidal, oval or obovoid, hyaline, and 6.0 to $10.0 \times$ 2.5 to $3.5 \mu \mathrm{m}$. Beta conidia have not been observed in culture on PDA (Mathew et al. 2015a; Thompson et al. 2011).

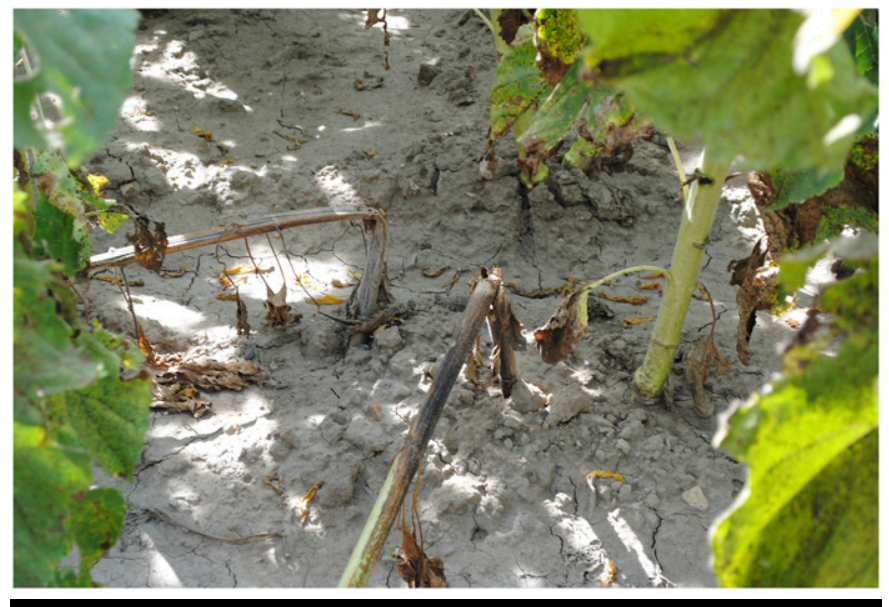

FIGURE 12

Lodging of sunflower plants severely affected by Phomopsis stem canker. 


\section{Pathogen Storage}

Diaporthe isolates can be stored on PDA slants for the long term at $4{ }^{\circ} \mathrm{C}$; PDA is prepared in $60 \mathrm{ml}$ glass jars following the protocol of Leslie and Summerell (2006). After autoclaving and cooling, PDA is inoculated with the mycelial plugs of Diaporthe isolates. The mycelial plugs should be taken from the leading edge of fresh Diaporthe isolates. After 2 weeks of incubation at $25^{\circ} \mathrm{C}$, contents of glass jars can be placed at $4^{\circ} \mathrm{C}$ for up to a year.

\section{Pathogenicity Tests}

In a study by Mathew et al. (2015a), a stem-wound method was adopted to compare aggressiveness among $D$. helianthi and D. gulyae isolates. Mycelial plugs (4 to $6 \mathrm{~mm}$ in diameter) taken from the margin of the growing colony cultured on PDA were used as inoculum. The stems of sunflower plants between the V4 and V6 growth stages (four to six true leaves) were wounded on the second internode and a Diaporthe-infested mycelial plug placed on the wound. The mycelial plug was attached to the stem wound with Parafilm to avoid dehydration. The pots were placed on the greenhouse benches at 22 to $25^{\circ} \mathrm{C}$ under a 16-h light/dark cycle. Disease severity was evaluated at 14 days after inoculation using a rating scale of 0 to 5 (Thompson et al. 2011). Symptoms caused by

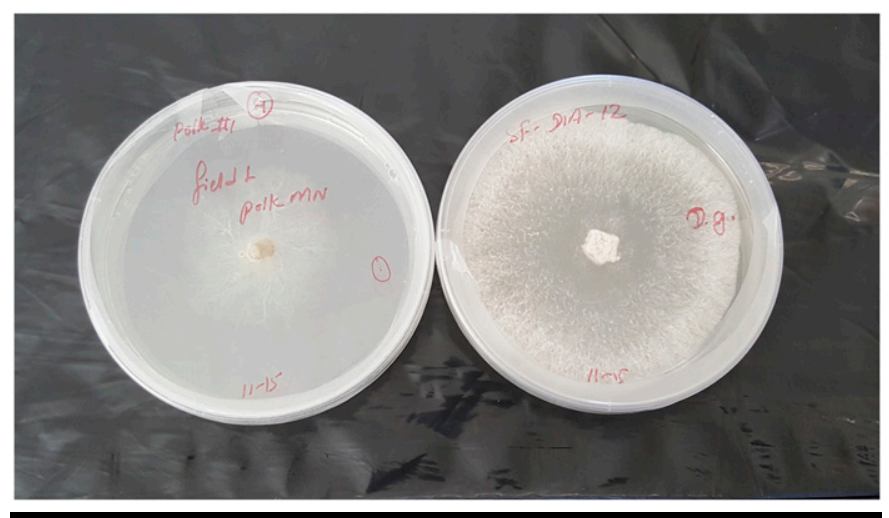

FIGURE 13

Culture growth characteristic of Diaporthe helianthi (left) and D. gulyae (right).

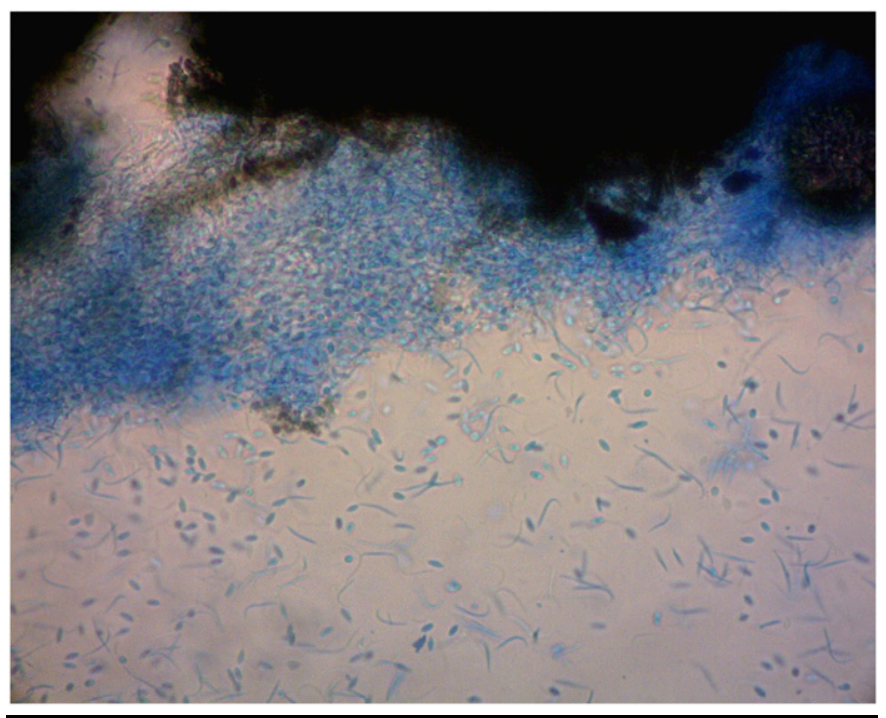

FIGURE 14

Both alpha and beta conidia characteristic of Diaporthe helianthi.
$D$. helianthi and D. gulyae appeared on the sunflower plants within 3 to 7 days. The Mathew et al. (2015a) study showed that D. gulyae produced brown-colored lesions on the stem, causing the sunflower plant to wilt, lodge, and die 3 days after inoculation. In contrast, D. helianthi caused tan-colored, elongated lesions at 7 days after inoculation with no plant mortality (Mathew et al. 2015a).

\section{Host: Sunflower (H. annuus L.)}

Disease: Bacterial stalk rot.

Pathogens: Pectobacterium carotovorum subsp. carotovorum (Jones 1901) Hauben et al. 1998 emend. Garden et al. 2003 (formerly known as Erwinia carotovora subsp. carotovora [Jones 1901] Bergey et al. 1923) and Pectobacterium atrosepticum (van Hall 1902) Garden et al. 2003 (formerly known as Erwinia carotovora subsp. atroseptica [van Hall 1902] Dye 1969). Further information on current bacterial taxonomy can be found (Bull et al. 2010).

Taxonomy: Kingdom Bacteria; phylum Proteobacteria; class Gamma Proteobacteria; order Enterobacteriales; family Enterobacteriaceae; genus Pectobacterium; and species $P$. carotovorum and $P$. atrosepticum.

\section{Signs and Symptoms}

Typical symptoms of bacterial stalk rot include green-black to black discoloration forming on the outside of stalks, and infection is aided by any type of mechanical injury. Infection often begins at entry points centered on petiole axils (Fig. 16). This is a site that collects water and serves as a favorable environment for bacterial residence and insect activity. Breakdown of tissues is odorless unless stems are in an advanced state of decomposition. In advanced stages of disease, a wet, slimy rot of internal tissues appears with a characteristic unpleasant odor of rotting potatoes. Infected stalks soften and dry up, becoming dark brown to black (Fig. 17); flowers and seeds may also be discolored. Stalks often lodge under the weight of maturing heads (Fig. 18) (Harveson et al. 2012).

Under conditions of high humidity, signs of the pathogen may be seen exuding out of wounds (Fig. 19), and severely affected plant tissues will eventually disintegrate. If the weather becomes warm

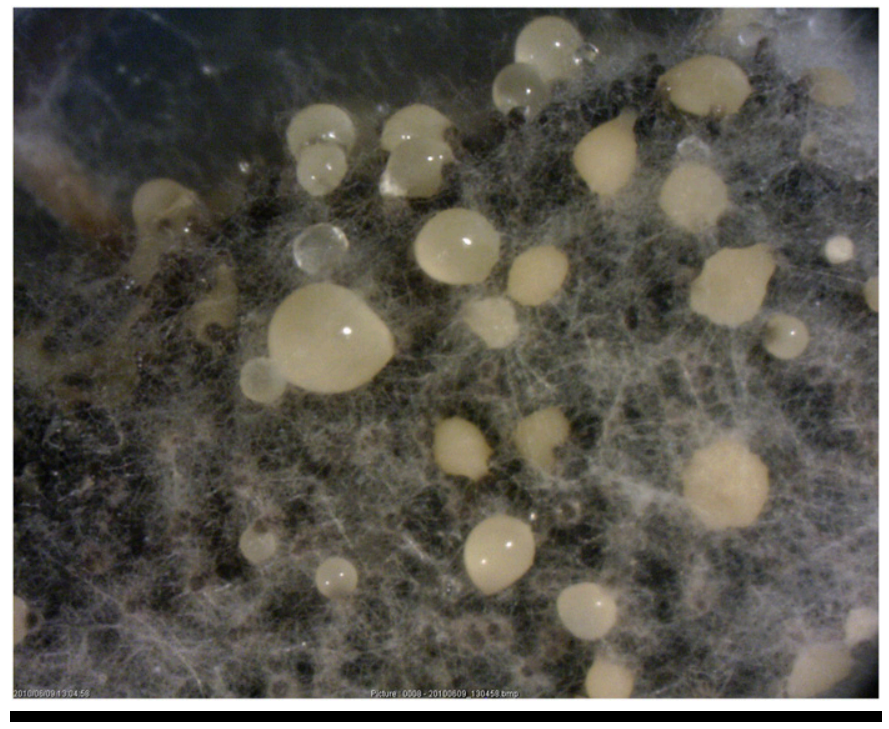

FIGURE 15

Pycnidia with masses of alpha conidia oozing out through ostioles, characteristic of Diaporthe gulyae. 
and dry, the affected tissues will dry out and turn black. As fermentation of the sugars in the plant occurs owing to bacterial activity, exudates and gases are formed. This action may then be followed by a foam appearing on infected stems (Fig. 20). This disease often occurs after extended wet periods late in the growing season, which suggests that only stressed or senescing plants are highly susceptible. The bacterial stalk rot pathogen is readily disseminated in and among sunflower fields by splashing rain and irrigation water, and it survives between sunflower crops in infected crop debris and as a pathogen on many other plants (see Host Range below) (Harveson et al. 2012; Schwartz and Harveson 2016).

\section{Host Range}

Species of Pectobacterium have been reported as pathogens of species in 16 different dicot plant families in 11 orders, and of species in 11 monocot families in 6 orders (Ma et al. 2007). An exception to the wide-host-range nature of Pectobacterium spp. is $P$. atrospeticum, which has been reported only on potato (Solanum tuberosum L.) and sunflower (Baştaş et al. 2009; Ma et al. 2007). Conversely, $P$. carotovorum causes soft rot of vegetable and ornamental plants including potato, sunflower, broccoli (Brassica oleracea L.), and calla lily (Zantedeschia spp.) (Arsenijevic 1970; Bradbury 1986; Gašic et al. 2013; Toth et al. 2003; Wright 1998). However, most plant species are rotted by $P$. carotovorum postharvest (Pérombelon and Salmond 1995).

\section{Geographic Distribution}

Bacterial stalk rot of sunflower has been observed occurring sporadically throughout the Great Plains of the United States (Gudmestad et al. 1984; Gulya et al. 2012), but it is generally not considered to be of major concern for production. It is also known to occur throughout Europe, Russia, Turkey, South Africa, and several other central African countries (e.g., Tanzania and Uganda) (Arsenijevic 1970; Baştaş et al. 2009; Gulya et al. 1997; Harveson et al. 2016; Raj and Wati 2005).

\section{Pathogen Isolation}

The pathogens are easily isolated from leaves or from blighted petioles and stalks. Tissue pieces taken from the margins between diseased and healthy areas can be lightly surface disinfested

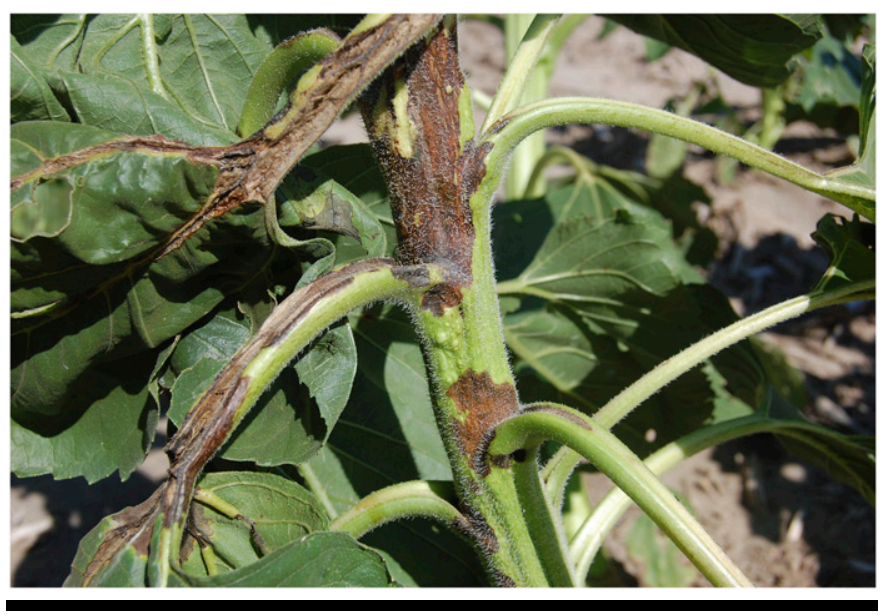

FIGURE 16

Bacterial stalk rot lesions beginning at attachments sites of petiole axils with stalk. utilizing $70 \%$ ethyl alcohol and/or $0.05 \%$ bleach (sodium hypochlorite) followed by rinsing in sterile water. Tissue pieces are then plated on various media, including nutrient broth-yeast medium, nutrient agar, yeast dextrose agar, or yeast extract peptone agar (Harveson et al. 2012; Schwartz and Harveson 2016).

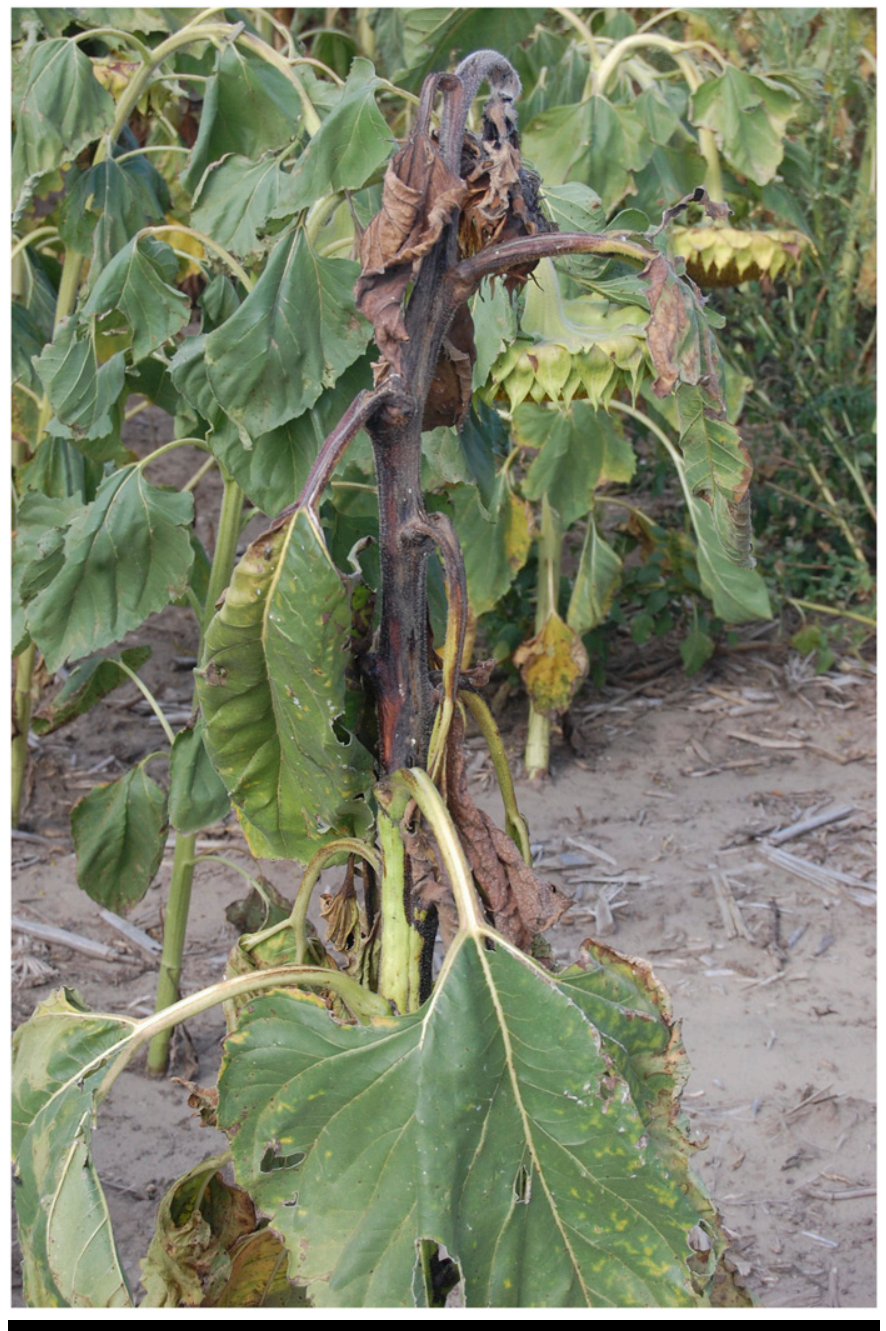

FIGURE 17

Sunflower stalk affected by bacterial rot.

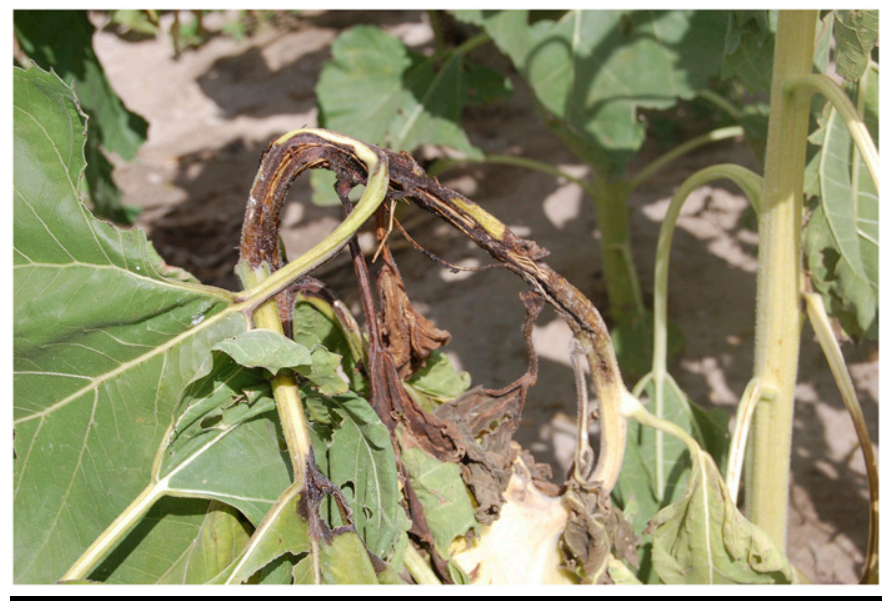

FIGURE 18

Severely diseased stalk lodging from weight of unaffected head. 


\section{Pathogen Identification}

The two species of Pectobacterium are in the soft-rot-causing group of plant pathogenic bacteria. Both pathogens are gramnegative rods with peritrichous flagella, catalase positive and oxidase negative, fermentative, facultatively anaerobic, and pectolytic (Schaad et al. 2001; Schwartz and Harveson 2016). They produce grayish white to creamy white colonies on most media and can be distinguished based on several physiological and biochemical properties. Pectobacterium cartovorum can grow at $37^{\circ} \mathrm{C}$ and does not utilize keto-methyl glucoside, whereas $P$. atroseptica cannot grow at $37^{\circ} \mathrm{C}$ but does utilize keto-methyl glucoside (Schaad et al. 2001).

\section{Pathogen Storage}

Long-term storage can be achieved from suspending lyophilized cultures in sterile glycerol (30 to $50 \%$ ) or $10 \%$ dry milk and then placing at $-70^{\circ} \mathrm{C}$ (Harveson and Schwartz 2007). Another relatively new method of storage can be employed through commercially available Microbank kits (PRO-LAB Diagnostics, Austin, TX). This technique utilizes sterile vials filled with a liquid growth medium and porous beads as carriers. Vials are inoculated with young (18- to 24-h) cultures. Vials are closed and inverted four

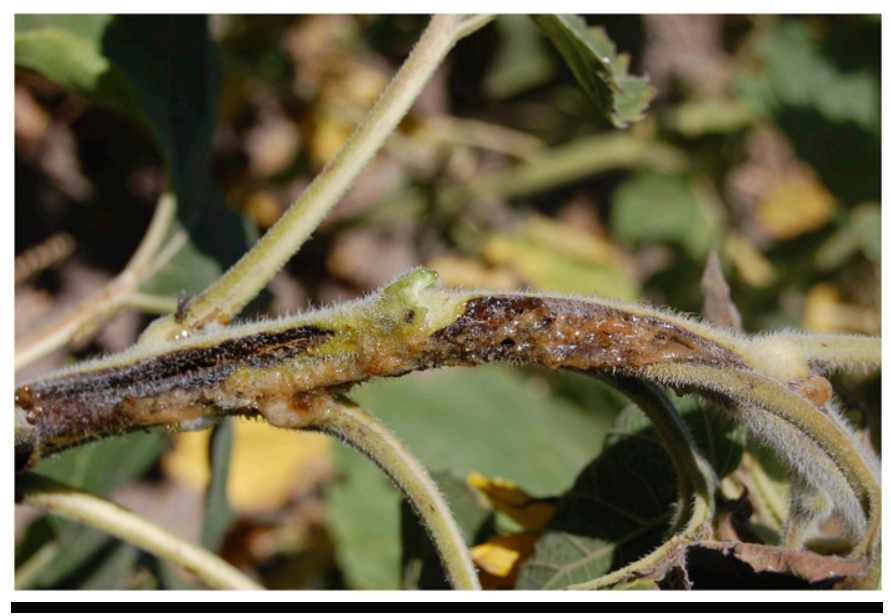

FIGURE 19

Bacterial growth emerging from infected stalk lesions.

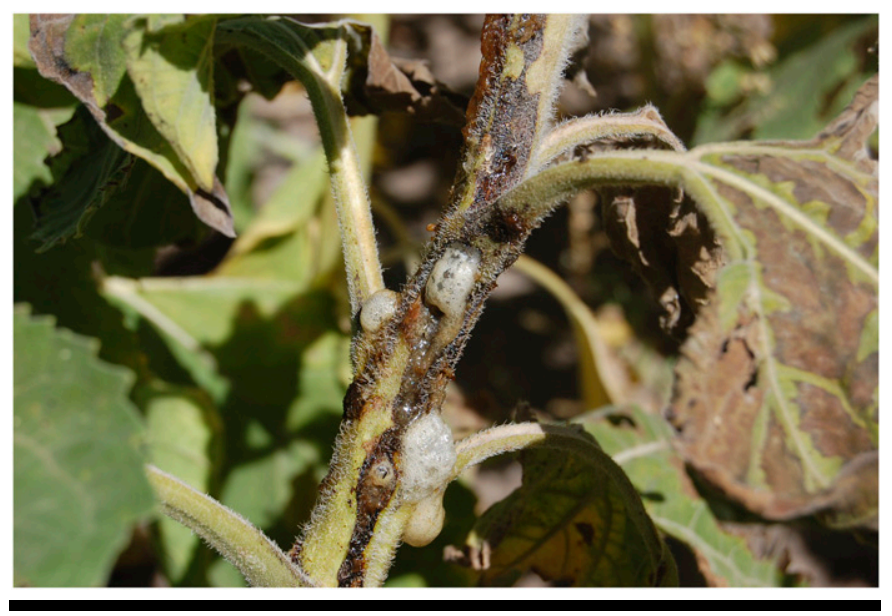

FIGURE 20

Foamy substance emerging from infected stalks after fermentation of sugars by pathogen.

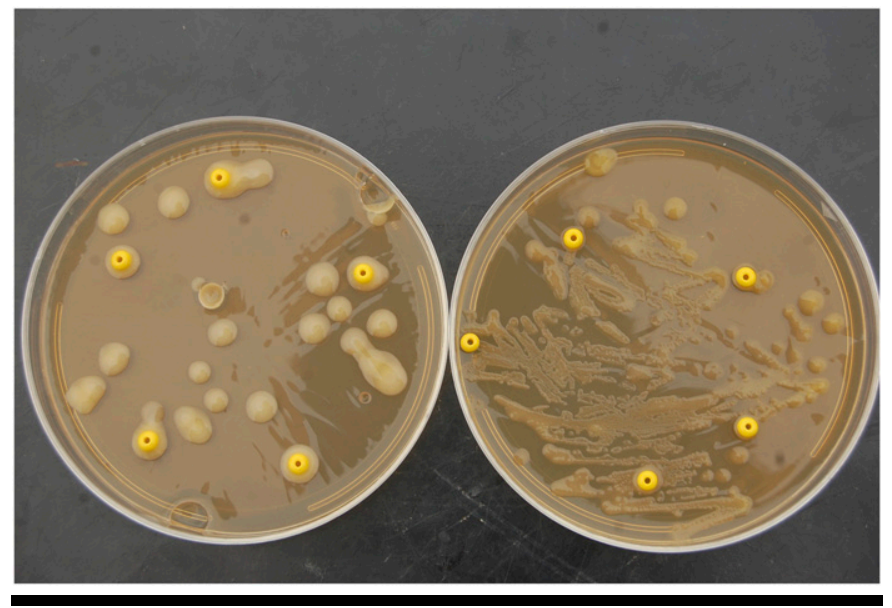

FIGURE 21

Retrieving bacterial pathogen after storage on beads.

to five times, and the bacteria will adhere to the beads. The vials are stored at $-70^{\circ} \mathrm{C}$ until needed. Inoculated beads may then be removed and used to directly streak to solid media (Fig. 21) or dropped into an appropriate liquid medium (see Pathogen Isolation above).

\section{Pathogenicity Tests}

For testing bacterial pathogens for pathogenicity, only young, healthy and vigorously growing plants should be used. Inoculum is prepared by growing cultures in nutrient broth and adjusting to $10^{6}$ to $10^{7} \mathrm{CFU} / \mathrm{ml}$. After wounding stems, adjusted inoculum is sprayed onto plants, or it can also be injected into the stem with a syringe and 26-gauge needles (Richeson 1981). Inoculated plants are placed into a mist chamber at temperatures ranging from 25 to $28^{\circ} \mathrm{C}$ or, alternatively, are covered with plastic bags for 12 to $14 \mathrm{~h}$. Inoculated plants can then be incubated in the greenhouse until symptom development (internal decay, external blackening of the stalk).

\section{Literature Cited}

Al Fadil, T. A., Jauneau, A., Martinez, Y., Rickauer, M., and Dechamp-Guillaume, G. 2009. Characterization of sunflower root colonization by Phoma macdonaldii. Eur. J. Plant Pathol. 124:93-103.

Arsenijevic, M. 1970. A bacterial soft rot of sunflower. Acta Phytopathol. Acad. Sci. Hung. 5:317-326.

Ash, G. J., Sakuanrungsirikul, S., Anschaw, E., Stodart, B. J., Crump, N., Hailstones, D., and Harper, J. D. I. 2010. Genetic characterization of a novel Phomopsis sp., a putative biocontrol agent for Carthamus lanatus. Mycologia 102:54-61.

Aveskamp, M. M., de Gruyter, J., and Crous, P. W. 2008. Biology and recent developments in the systematics of Phoma, a complex genus of major quarantine significance. Fungal Divers. 31:1-18.

Barnett, H. L., and Hunter, B. B. 1972. Illustrated Genera of Imperfect Fungi, 3rd Ed. Burgess Publishing, Minneapolis, MN.

Baştaş, K. K., Hekimhan, H., Madan, S., and Tor, M. 2009. First report of bacterial stalk and head rot disease caused by Pectobacterium astrosepticum on sunflower in Turkey. Plant Dis. 93:1352.

Bergey, D. H., Harrison, F. C., Breed, R. S., Hammer, B. W., and Huntoon, F. M. 1923. Bergey's Manual of Determinative Bacteriology, 1st Ed. Williams \& Wilkins, Baltimore, MD.

Boerema, G. H., de Gruyter, J., Noordeloos, M. E., and Hamers, M. E. C., eds. 2004. Phoma Identification Manual: Differentiation of Specific and Infraspecific Taxa in Culture. CABI Publishing, Wallingford.

Boerema, G. H., de Gruyter, J., and van Kestere, H. A. 1994. Contributions towards a monograph of Phoma (Coelomycetes)-III. 1. Section Plenodomus: Taxa often with a Leptosphaeria teleomorph. Persoonia 15: 431-487. 
Bradbury, J. F. 1986. Guide to Plant Pathogenic Bacteria. CAB International, Slough, U.K.

Bruni, O. 1965. Mancha negra del tallo del girasol y su relación con peste negra. Informe Técnico Nro. 48. INTA Pergamino, Pergamino, Argentina.

Bull, C. T., De Boer, S. H., Denny, T. P., Firrao, G., Saux, M. F., Saddler, G. S., Scortichini, M., Stead, D. E., and Takikawa, Y. 2010. Comprehensive list of names of plant pathogenic bacteria, 1980-2007. J. Plant Pathol. 92:551-592.

Carson, M. 1991. Relationship between black stem severity and yield losses in hybrid sunflower. Plant Dis. 75:1150-1153.

Dedić, B. 2012. Testing sunflower inbred lines for tolerance to Phoma black stem. Pestic. Fitomed. 27:299-303.

Dhingra, O. D., and Sinclair, J. B. 1995. Basic Plant Pathology Methods, 2nd Ed. CRC Press, Boca Raton, FL.

Donald, P. A., Bugbee, W. M., and Venette, J. R. 1986. First report of Leptosphaeria lindquistii (sexual stage of Phoma macdonaldii) on sunflower in North Dakota and Minnesota. Plant Dis. 70:352.

Donald, P. A., and Venette, J. R. 1983. A semi-selective medium for Phoma macdonaldii. N. Dak. Acad. Sci. 39:34.

Donald, P. A., Venette, J. R., and Gulya, T. J. 1987. Relationship between Phoma macdonaldii and premature death of sunflower in North Dakota. Plant Dis. 71:466-468.

Dye, D. W. 1969. A taxonomic study of the genus Erwinia III. The "herbicola" group. N. Z. J. Sci. 12:223-236.

Frezzi, M. J. 1968. Leptosphaeria lindquistii n. sp., forma sexual de Phoma oleracea var. helianthi-tuberosi Sacc., hongo causal de la 'mancha negra del tallo' del girasol (Helianthus annuus L.), in Argentine. Patol. Veg. 5:73-80.

Garden, L., Gouy, C., Chriten, R., and Samson, R. 2003. Elevation of three subspecies of Pectobacterium carotovorum to species level: Pectobacterium atrosepticum sp. nov., Pectobacterium betavasculorum sp. nov. and Pectobacterium wasabiae sp. nov. Int. J. Syst. Evol. Microbiol. 53:381-391.

Gašic, K., Gavrilovic, V., Ivanovic, Z., and Obradovic, A. 2013. First report of broccoli soft rot caused by Pectobacterium carotovorum subsp. carotovorum in Serbia. Plant Dis. 97:1504.

Gaudet, M. D., and Schulz, J. T. 1984. Association between a sunflower fungal pathogen, Phoma macdonaldii, and a stem weevil, Apion occidentale (Coleoptera, Curculionidae). Can. Entomol. 116:1267-1273.

Gudmestad, N. C., Secor, G. A., Nolte, P., and Straley, M. L. 1984. Erwinia carotovora as a stalk rot pathogen of sunflower in North Dakota. [Helianthus annuus.] Plant Dis. 68:189-192.

Gulya, T., Rashid, K. Y., and Masirevic, S. M. 1997. Sunflower diseases. Pages 263-379 in: Sunflower Technology and Production. A. A. Schneiter, ed. American Society of Agronomy, Madison, WI.

Gulya, T. J., Jr., and Charlet, L. D. 1984. Involvement of Cylindrocopturus adspersus in the premature ripening complex of sunflower. Phytopathology 74:869.

Gulya, T. J., and MacArthur, R. A. 1984. Incidence and severity of sunflower diseases in the Dakotas and Minnesota during the 1984 growing season. Page 6 in: Proceedings of the 7th Sunflower Research Forum, Fargo, ND, December 10-11, 1984.

Gulya, T. J., Rooney-Latham, S., Miller, J. S., Kosta, K., Murphy-Vierra, C., Larson, C., Vaccaro, W., Kandel, H., and Nowatzki, J. F. 2012. Sunflower diseases remain rare in California seed production fields compared to North Dakota. Online publication. Plant Health Prog. doi.org/10.1094/PHP-20121214-01-RS

Hajdu, F., Baumer, J. S., and Gulya, T. 1984. Occurrence of Phomopsis stem canker in Minnesota and North Dakota. Page 15 in: Proceedings of the Sunflower Research Workshop, Bismarck, North Dakota.

Harveson, R. M., Giesler, L. J., Jackson, T. A., Liu, B., Wegulo, S. N., and Korus, K. A. 2012. Sunflower Disease Profiles II: Head and Stalk and Wilt Diseases. EC1902. University of Nebraska, Cooperative Extension, Lincoln.

Harveson, R. M., Markell, S. G., Block, C. C., and Gulya, T. J. 2016. Compendium of Sunflower Diseases, 1st Ed. American Phytopathological Society, St. Paul, MN.

Harveson, R. M., and Schwartz, H. F. 2007. Bacterial diseases of dry edible beans in the central high plains. Online publication. Plant Health Prog. doi. org/10.1094/PHP-2007-0125-01-DG

Hauben, L., Moore, E. R. B., Vauterin, L., Steenackers, M., Mergaert, J., Verdonck, L., and Swings, J. 1998. Phylogenetic position of phytopathogens within the Enterobacteriaceae. Syst. Appl. Microbiol. 21:384-397.

Herr, L. J., Lipps, P. E., and Watters, B. H. 1983. Diaporthe stem canker of sunflower. Plant Dis. 56:800-802.

Jones, L. R. 1901. Bacillus carotovorus n. sp., die Ursache einer weichen Faulnis der Mohre. Zbl. Bakt. (Abt. II) 7:12-21, 61-68

Kandel, H., and Gulya, T. 2016. 2015 National Sunflower Crop Survey. In: Proceedings of the 38th Sunflower Research Forum, Fargo, ND, January $12-13,2016$.
Larfeil, C., Dechamp-Guillaume, G., and Barrault, G. 2002. Phoma macdonaldii Boerema-Helianthus annuus L. interaction. Helia 25:153-160.

Leslie, J. F., and Summerell, B. A., eds. 2006. The Fusarium Laboratory Manual. Blackwell, Ames, IA.

Ma, B., Hibbing, M. E., Kim, H.-S., Reedy, R. M., Yedidia, I., Breuer, J., Breuer, J., Glasner, J. D., Perna, N. T., Kelman, A., and Charkowski, A. O. 2007. Host range and molecular phylogenies of the soft rot enterobacterial genera Pectobacterium and Dickeya. Phytopathology 97:1150-1163.

MacDonald, W. C. 1964. Phoma black stem of sunflower. Phytopathology 54: 492-493.

Maric, A., and Schneider, R. 1979. Black spot of sunflowers in Yugoslavia and its causal agent Phoma macdonaldii Boerema. Phytopathol. Z. 94:226-233.

Masirevic, S., and Gulya, T. J. 1992. Sclerotinia and Phomopsis-Two devastating sunflower pathogens. Field Crops Res. 30:271-300.

Masirevic, S. N., Medic-Pap, S. S., Terzic, A. N., Dedic, B. P., and Balalic, I. D. 2014. Phoma macdonaldi on seed and its importance in etiology of Phoma black stem of sunflower. Jour. Nat. Sci. Matica Srpska Novi Sad 126:57-65

Mathew, F., Gulya, T. J., Jordahl, J., and Markell, S. 2018. First report of stem disease of soybean (Glycine max) caused by Diaporthe gulyae in North Dakota. Plant Dis. 102:240.

Mathew, F. M., Alananbeh, K. M., Jordahl, J. G., Meyer, S. M., Castlebury, L. A., Gulya, T. J., and Markell, S. G. 2015a. Phomopsis stem canker: A reemerging threat to sunflowers (Helianthus annuиs) in the United States. Phytopathology 105:990-997.

Mathew, F. M., Rashid, K. Y., Gulya, T. J., and Markell, S. G. 2015b. First report of Phomopsis stem canker of sunflower (Helianthus annuus) caused by Diaporthe gulyae in Canada. Plant Dis. 99:160.

Meyer, M. D., Zhang, G. R., Pedersen, D. K., and Bradley, C. A. 2009. First report of Phomopsis stem canker of sunflower in Illinois caused by Phomopsis helianthi. Plant Dis. 93:760.

Mihaljčević, M., Muntanola-Cvetkovic, M., Vukojevic, J., and Petrov, M. 1985. Source of infection of sunflower plants by Diaporthe helianthi in Yugoslavia. Phytopathol. Z. 113:334-342.

Miric, E., Aitken, E. A. B., and Goulter, K. C. 1999. Identification in Australia of the quarantine pathogen of sunflower Phoma macdonaldii (teleomorph: Leptosphaeria lindquistii). Aust. J. Agric. Res. 50:325-332.

Noordeloos, M. E., De Gruyter, J., van Eijk, G. W., and Roeijmans, H. J. 1993. Production of dendritic crystals in pure cultures of Phoma and Ascochyta and its value as a taxonomic character relative to morphology, pathology and cultural characteristics. Mycol. Res. 97:1343-1350.

Olson, T. R., Kontz, B., Gulya, T. J., Markell, S. G., and Mathew, F. M. 2017. First report of Diaporthe stewartii causing Phomopsis stem canker of sunflower (Helianthus annuus) in Minnesota. Plant Dis. 101:382.

Penaud, A., and Peres, A. 1994. Phoma du Tournesol. Oleoscope 15:37.

Pérombelon, M. C. M., and Salmond, G. P. C. 1995. Bacterial soft rots. Pages 1-20 in: Pathogenesis and Host Specificity in Plant Diseases, Vol. 1. Prokaryotes. U. S. Singh, R. P. Singh, and K. Kohmoto, eds. Pergamon, Oxford, U.K.

Raj, K., and Wati, L. 2005. Bacterial and viral diseases of sunflower. Pages 460-474 in: Diseases of Oil Crops. G. S. Saharan, N. Mehta, and M. S. Sangwan, eds. Indus, New Delhi, India.

Richeson, M. L. 1981. Etiology of a late season wilt in Helianthus annuus. Plant Dis. 65:1019-1021.

Roustaee, A., Costes, S., Dechamp-Guillaume, G., and Barrault, G. 2000. Phenotypic variability of Leptosphaeria lindquistii (anamorph: Phoma macdonaldii), a fungal pathogen of sunflower. Plant Pathol. 49:227-234.

Says-Lesage, V., Roeckel-Drevet, P., Viguié, A., Tourvieille, J., Nicolas, P., and Tourvieille de Labrouhe, D. 2002. Molecular variability within Diaporthel Phomopsis helianthi from France. Phytopathology 92:308-313.

Schaad, N. W., Jones, J. B., and Chun, W. 2001. Laboratory Guide for Identification of Plant Pathogenic Bacteria, 3rd Ed. American Phytopathological Society Press, St. Paul, MN.

Schwanck, A. A., Savary, S., Lepenneteir, A., Debaeke, P., Vincourt, P., and Willocquet, L. 2016. Predicting quantitative host plant resisteance against Phoma black stem in sunflower. Plant Pathol. 65:1366-1379.

Schwartz, H. F., and Harveson, R. M. 2016. Bacterial stalk and head rot. Pages 64-65 in: Compendium of Sunflower Disease and Insect Pests. R. M. Harveson, S. G. Markell, C. C. Block, and T. J. Gulya, eds. American Phytopathological Society Press, St. Paul, MN.

Seassau, C., Debaeke, P., Mestries, E., and Dechamp-Guillaume, G. 2010. Evaluation of inoculation methods to reproduce sunflower premature ripening caused by Phoma macdonaldii. Plant Dis. 94:1398-1404.

Sørensen, J. L., Mogensen, J. M., Thrane, U., and Anderson, B. 2009. Potato carrot agar with manganese as an isolation medium for Alternaria, Epicoccum and Phoma. Int. J. Food Microbiol. 130:22-26. 
Thompson, S. M., Tan, Y. P., Shivas, R. G., Neate, S. M., Morin, L., Bissett, A., and Aitken, E. A. B. 2015. Green and brown bridges between weeds and crops reveal novel Diaporthe species in Australia. Persoonia 35:39-49.

Thompson, S. M., Tan, Y. P., Young, A. J., Neate, S. M., Aitken, E. A. B., and Shivas, R. G. 2011. Stem cankers on sunflower (Helianthus annuus) in Australia reveal a complex of pathogenic Diaporthe (Phomopsis) species. Persoonia 27:80-89.

Toth, I. K., Bell, K. S., Holeva, M. C., and Birch, P. R. J. 2003. Soft rot erwinia: From genes to genomes. Mol. Plant Pathol. 4:17-30.

Udayanga, D., Xingzhong, L., McKenzie, E. H. C., Chukeatirote, E., Bahkali, A. H. A., and Hyde, K. D. 2011. The genus Phomopsis: Biology, applications, species concepts and names of common phytopathogens. Fungal Divers. 50: $189-225$.

van Hall, C. J. J. 1902. Bijdragen tot de kennis der bactereele plantenziekten. Doctoral thesis. University of Amsterdam, Netherlands. van Niekerk, J. M., Groenewald, J. Z., Farr, D. F., Fourie, P. H., Halleen, F., and Crous, P. W. 2005. Reassessment of Phomopsis species on grapevine. Australas. Plant Pathol. 34:27-39.

Vrandecic, K., Jurkovic, D., Riccioni, L., Cosic, J., and Duvnjak, T. 2010. Xanthium italicum, Xanthium strumarium, and Arctium lappa as new hosts for Diaporthe helianthi. Mycopathologia 170:51-60.

Wright, P. J. 1998. A soft rot of calla (Zantedeschia spp.) caused by Erwinia carotovora subspecies carotovora. N. Z. J. Crop Hortic. Sci. 26:331-334.

Wu, P. S., Du, H. Z., Zhang, X. L., Luo, J. F., and Fang, L. 2012. Occurrence of Phoma macdonaldii, the causal agent of sunflower black stem disease, in sunflower fields in China. Plant Dis. 96:1696.

Yang, S. M., Berry, R. W., Luttrell, L. E. S., and Vongkaysone, T. 1984. A new sunflower disease in Texas caused by Diaporthe helianthi. Plant Dis. 68: 254-255. 